\title{
Inovatyvus elgesys darbe: kai kurios psichometrinès klausimyno charakteristikos ir sąsajos su darbuotojų psichologiniu igalinimu bei vidine darbo motyvacija
}

\author{
Rasa GELEŽINYTE $\dot{E}^{1}$ \\ Vilniaus universitetas
}

\begin{abstract}
Santrauka. Inovacijas kuriantis darbuotojų elgesys yra ypač svarbus organizacijoms: igyvendindamos inovacijas jos geba sëkmingai konkuruoti rinkoje, spręsti savo vidaus problemas, tobulinti darbo metodus ir kita. Tyrimo tikslas. Šiuo tyrimu siekiama: 1) ịvertinti lietuviško inovatyvaus elgesio darbe vertinimo klausimyno (LIEDK) psichometrines charakteristikas; 2 ) išnagrinèti inovatyvaus elgesio sąsajas su darbuotoju psichologiniu igalinimu ir vidine darbo motyvacija. Metodika. Atliktas skerspjūvio tyrimas, taikytas patogiosios atrankos metodas, anketinèje apklausoje dalyvavo 283 ịvairių Lietuvos organizacijų darbuotojai. Rezultatai. Tyrimo rezultatai parodè, kad LIEDK pasižymi pakankamu konstrukto validumu ir vidiniu suderintumu. Taip pat nustatyta, kad psichologinis igalinimas ir vidinè darbo motyvacija yra teigiamai susiję su inovatyviu elgesiu darbe. Išvados. 1. Parengta patikima ir validi lietuviška inovatyvaus elgesio darbe vertinimo priemonè. 2. Inovatyvus darbuotoju elgesys yra teigiamai susijęs su jų vidine darbo motyvacija ir psichologiniu igalinimu.
\end{abstract}

Pagrindiniai žodžiai. Inovatyvus elgesys darbe, psichologinis ịgalinimas, vidinė motyvacija.

\section{Ivadas}

Šiais laikais organizacijos susiduria su būtinybe prisitaikyti prie nuolat kintančių išorès reikalavimų, siūlyti naujoves rinkoje ir taikyti jas savo veikloje. Inovacijas diegiančioje organizacijoje i šiuos procesus siekiama ịtraukti visus darbuotojus, todèl ir moksliniuose tyrimuose vis dažniau akcentuojama inovatyvaus darbuotojų elgesio tyrimų svarba. Inovatyvus elgesys neatsiejamas nuo inovacijos reiškinio, kuris tyrinejjamas, pirma, kaip produktas - potencialiai naudinga naujové, kuria siekiama išspręsti tam tikrą problemą arba pagerinti esamą padètį, ir, antra, kaip naujovès kūrimo ir igyvendinimo procesas (Van de Ven, 1986; Messmann \& Mulder, 2012).

Inovaciju problematika moksliškai tiriama nuo dvidešimto amžiaus pradžios, tačiau individo vaidmens ir reikšmès inovacijų procese psichologiniai tyrimai prasidejjo tik devintame dešimtmetyje (Kanter, 1988; West \& Farr, 1989). Mokslinèje literatūroje inovatyvus elgesys darbe (IED, angl. innovative work behaviour, IWB) apibrèžiamas kaip darbuotojo veiksmai, nukreipti ị naujų idejjų kūrimą ir igyvendinimą, siekiant išspręsti tam tikrą problemą ar pagerinti esamą padèti bet kuriame organizacijos lygmenyje (West \& Farr, 1989; Scott \& Bruce, 1994; Messmann \& Mulder, 2011, 2012; Kleysen \& Street, 2001). Inovatyviam darbuotojų elgesiui tirti naudojamos viendimensès (pvz., Scott \& Bruce, 1994) ir daugiadimensès (pvz., Messmann \& Mulder, 2012; Dorenbosch, van Engen, \& Verhagen, 2005) skalès, tačiau, kad ir kokia būtu metodo struktūra, IED konstrukte dažniausiai išskiriamos šios elgesio formos (Kleysen \& Street, 2001; De Jong \& Den Hartog, 2010; Messmann \& Mulder, 2012 ir kt.): 1) problemu atpažinimas, galimybiu tyrimas: tiriamos darbo problemos ir poreikiai, ieškoma galimybių pagerinti situaciją; 2) idèju kūrimas: kuriamos idejjos, kaip išspręsti konkrečią problemą arba pagerinti dabartinę padètį; 3) idèjos rémimas: siekiama bendradarbių ir vadovų palaikymo, kad idejja būtų igyvendinta; 4) idèjos igyvendinimas: idèja igyvendinama praktikoje; jei reikia, koreguojamas ịgyvendinimo procesas, ịvertinami rezultatai.

Mokslininkai tiria IED sąsajas su ịvairių lygmenų veiksniais: organizacijos ir grupės (pvz., Young, 2012), vadovavimo (pvz., Pieterse, van Knippenberg, Schippers, \& Stam, 2009), darbo charakteristikų (pvz., Ramamoorthy, Flood, Slattery, \& Sardessai, 2005), individo charakteristikų (pvz., Scott \& Bruce, 1994). Šiame tyrime analizuojamos inovatyvaus elgesio individualios motyvacinès prielaidos - psichologinis ịgalinimas ir vidiné darbo motyvacija.

Psichologinis igalinimas (angl. psychological empowerment) apibūdinamas kaip darbuotojo galios būsena, susidedanti iš suvokiamos kompetencijos, darbo prasmės, poveikio ir autonomijos (Spreitzer, 1995; Thomas \& Velthouse, 1990). Pabrěžtina, kad psichologinis iggalinimas atspindi ne objektyviai darbuotojui suteikiamą galią savarankiškai priimti sprendimus ir juos įgyvendinti, o tai, kaip ją patiria ir suvokia individas (pvz., Thomas \& Velthouse, 1990). Elgesį motyvuoja ne formaliai priskirta, o suvokta ir priimta galia (pvz., Conger \& Kanungo, 1988). Šiame tyrime psichologinis igalinimas traktuojamas kaip būsena, apimanti du suvokiamos galios aspektus suvokiamą gebėjimą atlikti darbo užduotis ir energiją, skatinančią jas atlikti (Thomas \& Velthouse, 1990; Tvarijonavičius, 2014). Kaip rodo užsienyje atlikti tyrimai (pvz., Pieterse et al., 2009), psichologinis igalinimas yra 
teigiamai susijęs su inovatyviu elgesiu darbe, tačiau tyrimų, patvirtinančių šią sąsają Lietuvos darbuotojų imtyje, iki šiol nèra atlikta.

Su inovatyviu elgesiu darbe siejama ir vidinė motyvacija (angl. intrinsic motivation). Ji pasireiškia asmeniui atliekant veiklą dẻl jaučiamo susidomėjimo ir spontaniško pasitenkinimo, gaunamo iš pačios veiklos, o ne dẻl išorinių paskatų (Gagné \& Deci, 2005). Pažymètina, kad vidinès motyvacijos konstruktas skiriasi nuo psichologinio ịgalinimo, nes vidujai motyvuotas asmuo nebūtinai jausis ịgalintas (Tvarijonavičius, 2014).

Vidinè motyvacija yra viena dažniausiai tiriamų kūrybiškumo - konstrukto, glaudžiai susijusio su inovatyviu elgesiu, - prielaidų. Daugelis tyrimų rodo, kad vidujai motyvuoti asmenys dažniau elgiasi kūrybiškai (t. y. kuria naujas ir potencialiai naudingas idejjas), be to, jų sukurtos idejos ekspertų vertinamos kaip originalesnès ir naudingesnès nei tų, kurie kuria veikiami išorinių paskatų (pvz., Amabile, 1985). Vidinė motyvacija siejasi su kognityviu lankstumu, susitelkimu ị užduotị, atkaklumu, o tai skatina kūrybiškumo pasireiškimą (pvz., De Dreu, Baas, \& Nijstad, 2012). Kita vertus, apie vidinės motyvacijos reikšmę inovatyviam elgesiui (ne tik idejjų kūrimui, bet ir jų ịgyvendinimui) žinoma mažiau. Tyrimai patvirtina, kad darbuotojai, pasižymintys stipria vidine motyvacija, iš tiesų dažniau elgiasi inovatyviai (pvz., Devloo, Anseel, Beuckelaer, \& Salanova, 2015), tačiau nepakanka tyrimų, kuriuose ši sąsaja būtų nagrinèjama atsižvelgiant $i$ inovatyvaus elgesio dimensijas.

Apibendrinant - inovatyvus elgesys darbe ir su juo susiję psichologiniai veiksniai yra vis dažniau tiriami užsienio mokslininkų. Siekiama apimti kuo išsamesni inovatyvaus elgesio prielaidų spektrą, pradedant organizacijų ypatybėmis ir baigiant darbuotojų charakteristikomis. Lietuvoje inovatyvus elgesys darbe ir jo psichologiniai aspektai iki šiol nebuvo tirti, nebuvo ir moksliškai pagrịsto lietuviško klausimyno, kuriuo galètų būti vertinama darbuotojų inovatyvaus elgesio raiška. Tyrimo tikslas - įvertinti inovatyvaus elgesio darbe vertinimo lietuviško klausimyno kai kurias psichometrines charakteristikas, taip pat išnagrinėti šio elgesio sąsajas su vidine darbo motyvacija ir psichologiniu igalinimu.

\section{Metodika}

\subsection{Tyrimo dalyviai}

Tyrime dalyvavo 283 asmenys (211 moterų, 72 vyrai), dirbantys ịvairiose Lietuvos organizacijose. Tyrimo dalyvių amžius - nuo 19 iki 62 metų $(\mathrm{M}=33,69, \mathrm{SD}=9,75) .159$ (56,2 proc.) tyrimo dalyviai dabartinèje organizacijoje dirba nuo 1 iki 3 metų, 61 (21,6 proc.) - nuo 4 iki 10 metų, 59 (20,8 proc.) - daugiau nei 10 metų (4 respondentai informacijos nepateikè). 237 (83,7 proc.) respondentai yra ịgiję aukštajị išsimokslinimą, 24 (8,5 proc.) - vidurinị, 19 (6,7 proc.) - aukštajị neuniversitetinị arba aukštesniji ir 3 (1,1 proc.) - profesinị. $219(77,4$ proc.) apklaustų darbuotojų nurodè einantys nevadovaujamas pareigas. 159 (56,2 proc.) dirba privataus, 121 (42,8 proc.) - viešojo sektoriaus organizacijose ( 3 respondentai ị ši klausimą neatsakè).

\subsection{Tyrime naudoti instrumentai}

Demografinių duomenu anketa, susidedanti iš klausimų apie lytị, amžių, darbo stažą organizacijoje, išsilavinimą, einamas pareigas, ekonominị sektorių.

Lietuviškas inovatyvaus elgesio darbe klausimynas (LIEDK). Tai inovatyvaus elgesio tyrimo metodas, kuriuo vertinamas inovatyvaus elgesio darbe pasireiškimas. Jis buvo kuriamas vadovaujantis Simms (2008) pateiktomis skalių kūrimo gairèmis. Pirmiausia buvo atlikta literatūros analizė ir išskirtos penkios inovatyvaus elgesio darbe formos (dimensijos): domejjimasis, idejų tyrimas ir kūrimas, idejjų išbandymas ir ịvertinimas, paramos siekimas ir idejų igyvendinimas. Pažymėtina, kad, siekiant kuo išsamiau atspindèti ịvairius inovatyvaus elgesio aspektus ir atsižvelgiant ì kitų autorių pateikiamus argumentus (pvz., Cropley, 2006), buvo ịtraukta ,idèjų išbandymo ir ịvertinimo" elgesio forma. Kiekvienai dimensijai buvo priskirti teiginiai, kurių sąrašas parengtas, pirma, remiantis užsienio autorių analogiškų klausimynų analize (Messmann \& Mulder, 2012; De Jong \& Den Hartog, 2010; Dorenbosch et al., 2005; Kleysen \& Street, 2001 ir kt.) ir, antra, buvo įtraukti papildomi teiginiai. Pradinị sąrašą sudare 96 teiginiai. Pirmiausia šis sąrašas buvo trumpinamas, atsisakyta pasikartojančių teiginių, koreguojamos teiginių formuluotès. Tyrimui parengtas 29 teiginių klausimynas, kuriuo vertinamos penkios inovatyvaus elgesio dimensijos: domejjimasis (pvz., „Domiuosi profesinès srities naujovėmis“); idejju tyrinejjimas ir kūrimas (pvz., „Sugalvoju naujų būdų (metodų), kaip atlikti ịprastas darbo užduotis“); idẻju išbandymas ir ịvertinimas (pvz., „Prieš ịgyvendindamas (a) darbe naujas idejjas pirmiausia patikrinu, kaip jos veikia praktikoje“); paramos siekimas (pvz., „Akcentuoju, kodèl mano idejos yra reikalingos ir svarbios”) ir ideju igyvendinimas (pvz., „Aktyviai igyvendinu savo idejas praktikoje“). LIEDK konstrukto validumas buvo vertinamas tiriamaja faktorių analize ir nustatant inovatyvaus elgesio koreliacinius ryšius su iniciatyvumo ir permainų vengimo rodikliais.

Iniciatyvumas vertintas keturiais teiginiais iš Frese, Fay, Hilburger, Leng ir Tag (1997) iniciatyvumo skalès. Teiginio pavyzdys: „Jei tik kas nors vyksta ne taip, aš neatidèliodamas (-a) ieškau problemos sprendimo“. Skalès Cronbacho alfa lygi 0,827 . 
Permainu vengimas vertintas Oreg (2003) pasipriešinimo pokyčiams skalès trumpalaikio susitelkimo poskale, kurią sudaro keturi teiginiai, teiginio pavyzdys: „Man nepatinka net tokie pokyčiai, kurie galètų pagerinti mano gyvenimą“. Skalès Cronbacho alfa lygi 0,691.

Psichologinis igalinimas vertintas Tvarijonavičiaus ir Bagdžiūnienès (2013) Lietuvišku psichologinio ịgalinimo klausimynu, kurị sudaro 15 teiginių, pavyzdžiui, „Mano darbas man atrodo prasmingas“, „Kai reikia, aš galiu priimti sprendimus darbe“, „Aš esu kompetentingas tinkamai atlikti savo darbą“. Skalès Cronbacho alfa lygi 0,897.

Vidine motyvacija vertinta Grant (2008) sukurta skale, kurią sudaro keturi teiginiai. Respondentams pateikiamas ịvadinis klausimas: „Kodèl Jūs dirbate šị darbą? Todèl, kad...“; teiginio pavyzdys: „, ..> dirbti jị smagu“. Skalès Cronbacho alfa lygi 0,911 .

Visiems tyrimo metodams gauti autorių leidimai. Inovatyvaus elgesio teiginiai vertinami nuo 1 balo - „niekada“ iki 5 - „labai dažnai / visada“, kitose priemonėse naudota 5 balų Likerto skalè nuo 1 - „visiškai nesutinku“ iki 5 „visiškai sutinku“. Aukštesnis atsakymų į kiekvienos skalès teiginius vidurkio ịvertis žymi labiau išreikštą tiriamą charakteristiką arba dažniau atliekamą elgesị.

\subsection{Tyrimo eiga}

Tyrimas buvo vykdomas $2015 \mathrm{~m}$. balandį-gegužę. Apklausos imtis sudaryta taikant patogiosios atrankos metodą. Dauguma respondentų (235) pilde internetines, kiti (48) - popierines anketas. Visi tyrimo dalyviai buvo supažindinami su apklausos pobūdžiu, užtikrintas pateikiamų duomenų konfidencialumas ir anonimiškumas. Respondentai turèjo galimybę užpildyti anketą jiems patogiu metu.

\section{Rezultatai}

LIEDK vidinè struktūra buvo tikrinama principinių komponenčių metodu, naudojant varimax sukinį. Duomenys faktorių analizei tinkami (KMO $=0,922$, Bartleto sferiškumo testo $\mathrm{p}<0,001)$. Rezultatai patvirtino teorinę inovatyvaus elgesio dimensijų struktūrą: gauta, kad LIEDK teiginiai sudaro penkis faktorius ir paaiškina 67,684 proc. duomenų išsibarstymo. Faktorių svoriai kiekviename faktoriuje svyruoja nuo 0,490 iki 0,825. Pašalinus šešis teiginius, kurių svoris nesiekè 0,400, galutinèje klausimyno versijoje liko 23 teiginiai (po 4-5 teiginius kiekvienoje skalèje, apibūdinančioje skirtingas IED formas). Visų LIEDK poskalių ir bendro klausimyno vidinis suderintumas pakankamai aukštas: poskalių Cronbacho alfa koeficientai svyruoja nuo 0,744 iki 0,892, o viso klausimyno - 0,938.

LIEDK konstrukto validumas vertintas skaičiuojant visuminio IED rodiklio koreliacijas su iniciatyvumo rodikliu, matuojančiu panašų ị IED konstruktą ir jam pagal prasmę priešingu permainų vengimo rodikliu. Frese, Kring, Soose ir Zempel (1996) iniciatyvumą apibūdina kaip „elgesio sindromą“ (p. 38), pasireiškiantị specifiniu asmens požiūriu i

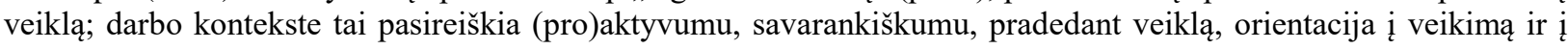
tikslą, atkaklumu susidūrus su kliūtimis. Iniciatyvumas turètų būti teigiamai susijęs su inovatyviu elgesiu. Permainų vengimas atspindi asmens polinkį vengti net tokių pokyčių, kurie galètų jam suteikti ilgalaikès naudos. Teigiama, kad šis vengimas kyla dèl polinkio vengti net trumpalaikių nepatogumų, kuriuos sukelia pokyčiai (Oreg, 2003). Šis konstruktas turètų būti neigiamai susijęs su IED, nes inovatyviai besielgiantis darbuotojas sąmoningai siekia konstruktyvių pokyčių, o vengiantis permainų asmuo, atvirkščiai, pokyčių vengia net tuomet, kai jaučia, kad jie galètų būti naudingi.

Rezultatai rodo, kad yra statistiškai reikšminga teigiama IED rodiklio koreliacija su iniciatyvumu (Spearmano rho $=0,570, \mathrm{p}<0,001)$, ir tai reiškia, kad iniciatyvumas turi panašumų su IED, tačiau nèra jam identiškas. O štai permainų vengimas su bendru IED rodikliu koreliuoja neigiamai (Spearmano rho $=-0,246, \mathrm{p}<0,001$ ), taigi galima teigti, kad LIEDK matuoja konstruktą, kurio prasmė yra priešinga permainų vengimui.

Siekiant išsiaiškinti, kaip inovatyvus elgesys siejasi su motyvacinemis charakteristikomis (psichologiniu igalinimu ir vidine motyvacija), atlikta koreliacinè analizè. Lentelejje pateikti Spearmano koreliacijos koeficientai rodo, kad abi motyvacinès charakteristikos yra susijusios su inovatyviu elgesiu ir jo dimensijomis. Vidinè motyvacija stipriausiai siejasi su idejų igyvendinimo dimensija, o psichologinis igalinimas - su paramos siekimo ir idejju igyvendinimo dimensijomis.

Lentelè. Inovatyvaus elgesio ir jo dimensijų koreliacijos su psichologinio ịgalinimo ir vidinès motyvacijos rodikliais

\begin{tabular}{|c|c|c|c|c|c|c|}
\hline & $\begin{array}{l}\text { Inovatyvus } \\
\text { elgesys darbe }\end{array}$ & Domèjimasis & $\begin{array}{c}\text { Idèjų } \\
\text { tyrinėjimas } \\
\text { ir kūrimas }\end{array}$ & $\begin{array}{c}\text { Idèjų } \\
\text { išbandymas ir } \\
\text { ịvertinimas }\end{array}$ & $\begin{array}{l}\text { Paramos } \\
\text { siekimas }\end{array}$ & $\begin{array}{c}\text { Idèjų } \\
\text { igyvendinimas }\end{array}$ \\
\hline $\begin{array}{l}\text { Psichologinis } \\
\text { igalinimas }\end{array}$ & $0,517 * *$ & $0,352 * *$ & $0,414 * *$ & $0,368 * *$ & $0,460 * *$ & $0,462 * *$ \\
\hline $\begin{array}{l}\text { Vidinè } \\
\text { motyvacija }\end{array}$ & $0,439 * *$ & $0,276^{* * *}$ & $0,393 * *$ & $0,311 * *$ & $0,355^{* *}$ & $0,429 * *$ \\
\hline
\end{tabular}

Pastaba. ** $\mathrm{p}<0,001$. 


\section{Rezultatų aptarimas}

Tyrimu pirmiausia buvo siekiama parengti lietuvišką inovatyvaus elgesio darbe vertinimo klausimyną (LIEDK) ir pagrịsti kai kurias jo psichometrines charakteristikas. Gauti pirminiai rezultatai leidžia teigti, kad metodas pasižymi pakankamu konstrukto validumu ir vidiniu suderintumu, o norint išsamiau paanalizuoti metodą, reikia platesni tyrimai didesnejje imtyje ir ịtraukiant daugiau validumo vertinimo kriterijų.

Taip pat buvo siekiama išsiaiškinti, ar darbuotoju vidinè motyvacija ir psichologinis igalinimas siejasi su inovatyviu elgesiu darbe. Atskleista, kad vidinè motyvacija yra susijusi su inovatyviu elgesiu, o tai atitinka užsienio autorių tyrimu rezultatus (pvz., Devloo et al., 2015). Vidinès motyvacijos ir IED sąsają iš dalies galima paaiškinti Amabile (1988) komponentų modeliu, pagal kurị kūrybiškam elgesiui (t. y. naujų ir naudingų idejjų kūrimui) reikia trijų veiksnių sąveikos: igūdžių toje srityje, kurioje norima kurti, kūrybinių igūdžių ir vidinės užduoties motyvacijos. Anot Amabile (1988), visi trys veiksniai svarbūs, tačiau reikšmingiausia yra vidinė motyvacija - jos trūkumo igūdžiai kompensuoti negali, tačiau stipri vidinė motyvacija iš dalies gali atsverti menkus ịūdžius. Teigiama, kad būtent nuo vidinès motyvacijos priklauso, kaip individas išnaudos turimą potencialą kurti (Amabile, 1988). Vidiniu paskatų veikiamas asmuo yra linkęs tyrinèti, mokytis, tobulinti gebèjimus, ieškoti naujovių ir iššūkių (Ryan \& Deci, 2000), o tai galima sieti ne tik su idèjų kūrimu, bet ir su IED apskritai: darbuotojas, siekiantis sẻkmingai igyvendinti savo idèją, turi ją analizuoti, tirti darbo aplinką ir socialinị kontekstą visuose inovacijos etapuose, be to, jis turi būti nuolat pasirengęs įgyti naujų žinių ir tobulinti igūdžius, nes inovacijos procesas yra sunkiai nuspejjamas ir ypač intensyvus žinių plètimo prasme (Kanter, 1988). Tai patvirtina šio tyrimo rezultatai: vidinė motyvacija yra reikšmingai susijusi ne tik su doméjimusi naujovėmis, idėjų kūrimu, jų išbandymu ir paramos joms siekimu, bet ir idèjų igyvendinimu praktikoje. Šis atradimas ypač svarbus,nes literatūroje vidinè motyvacija ịprastai siejama su idèjų kūrimu (kūrybiškumu), o apie jos reikšmę idèjų igyvendinimui kalbama nedaug.

Tyrime taip pat buvo siekiama išsiaiškinti, ar IED siejasi su darbuotojų psichologiniu igalinimu. Gauti rezultatai patvirtina užsienyje atliktų tyrimų rezultatus (pvz., Pieterse et al., 2009): psichologinis iggalinimas yra susijęs su inovatyviu elgesiu darbe. Psichologiškai igalinti darbuotojai pasitiki savo gebėjimais, jaučiasi turintys laisvès darbo atlikimo atžvilgiu ir galintys priimti svarbius sprendimus darbe, be to, jie tiki savo darbo prasme ir veikia su užsidegimu. Visa tai sukuria palankią psichologinę terpę ịsitraukti į inovacijas kuriantị elgesị - veiklą, kuri pasižymi iqvairiomis rizikomis (Janssen, Vliert, \& West, 2004). Svarbu pasakyti, kad šiame tyrime psichologinis igalinimas stipriausiai siejasi su paramos siekimo ir idejjų igyvendinimo dimensijomis - būtent tomis elgesio formomis, kurios gali būti laikomos rizikingiausiomis individualiu, padalinio ar visos organizacijos atžvilgiu. Būtent nuo šių elgesio formų priklauso galutinis IED rezultatas - ar idejja taps konkrečiu produktu, darbo metodu, procedūra ir pan. Taigi, psichologinis igalinimas turi reikšmès darbuotojo pasirinkimui, ar, turint naują ir potencialiai naudingą idejją, imtis tolesnių veiksmų - pristatyti ją kitiems ir siekti iggvendinti. Tai galima aiškinti šiais būdais. Pirma, psichologiškai igalinti darbuotojai palankiau vertina savo inovatyvių veiksmų rezultatus ir, tikètina, patiria mažiau grèsmių, susijusių su IED (galbūt blogesnis ịvaizdis, konfliktai su bendradarbiais ar vadovu ir pan.). Antra, net jei skirtingu psichologinio igalinimo lygiu pasižymintys asmenys patiria panašias grèsmes, tikètina, kad psichologiškai igalinti darbuotojai, užuot susitelkę i šias grèsmes, koncentruosis ị numatomus teigiamus rezultatus, pavyzdžiui, būsimą inovacijos naudą, pasitenkinimą inovacijos rezultatais. Abiem atvejais numatomų IED rezultatų vertinimai prisideda prie to, kad psichologiškai igalinti darbuotojai yra linkę elgtis inovatyviai.

Apibendrinant - tyrimo rezultatai patvirtina darbuotojo motyvacinių veiksnių - psichologinio iggalinimo ir vidinès motyvacijos - reikšmę inovatyviam elgesiui. Taigi tam, kad darbuotojai kurtų idèjas ir siektų jas igyvendinti praktikoje, svarbūs ne tik sugebèjimai, bet ir aukšta vidinè motyvacija bei psichologinis ịgalinimas. Atsižvelgiant i tai, organizacijos, kurios inovatyvumą laiko vertybe, turètų sukurti sąlygas darbuotojams stiprinti vidinę motyvaciją ir psichologinio igalinimo patyrimą, pavyzdžiui, teikti daugiau autonomijos, labiau ịtraukti ị sprendimų prièmimo procesus, padèti darbuotojams tobulinti profesines kompetencijas ir skatinti pasikliauti savo kompetencijomis.

\section{Išvados}

- Lietuviškas inovatyvaus elgesio darbe vertinimo klausimynas pasižymi pakankamai geru konstrukto validumu ir patikimumu.

- Psichologinis iggalinimas ir vidinè darbo motyvacija yra teigiamai susiję su inovatyviu elgesiu darbe: darbuotojai, kurie jaučiasi psichologiškai igalinti, taip pat kurių aukšta vidinė darbo motyvacija, yra linkę issitraukti i su inovacijomis susijusius procesus organizacijoje.

- Vidinè darbo motyvacija ir psichologinis igalinimas stipriausiai siejasi su organizacijoms ypač svarbia inovatyvaus elgesio sritimi - idèjų igyvendinimu.

\section{Padèka}

Dèkoju tyrimo vadovei doc. dr. Daliai Bagdžiūnienei už vertingas įžvalgas rengiant straipsnị. 


\title{
Innovative work behaviour: Some psychometric properties of the questionnaire and relationships with psychological empowerment and intrinsic work motivation
}

\author{
Rasa GELEŽINYTE் \\ Vilnius University \\ Corresponding author: rasa.gelezinyte@fsf.vu.lt
}

\begin{abstract}
Employee behaviour which creates innovations is especially important for organisations: due to innovations, they successfully compete in the market, solve problems inside the organisations, improve work methods, etc. The aim of this study is twofold: (1) to assess some psychometric characteristics of the Lithuanian innovative work behaviour questionnaire (LIEDK); (2) to explore innovative work behaviour relationships with employees' psychological empowerment and intrinsic work motivation. 283 employees from various Lithuanian organisations participated in the cross-sectional study. The results proved the sufficient construct validity and internal consistency of LIEDK. It was also found that psychological empowerment and intrinsic motivation are positively related to innovative work behaviour. Conclusions: (1) Lithuanian innovative work behaviour questionnaire is a new research tool, which meets the requirements of validity and reliability; (2) Innovative work behaviour is positively related to employees' psychological empowerment and intrinsic work motivation.

Keywords. Innovative work behaviour, psychological empowerment, intrinsic motivation.
\end{abstract}




\section{Literatūra}

Amabile, T. M. (1985). Motivation and creativity: Effects of motivational orientation on creative writers. Journal of Personality and Social Psychology, 48 (2), 393-399.

Amabile, T. M. (1988). A model of creativity and innovation in organizations. Research in Organizational Behavior, 10 (1), $123-167$.

Conger, J. A., \& Kanungo, R. N. (1988). The empowerment process: Integrating theory and practice. Academy of Management Review, 13 (3), 471-482.

Cropley, A. (2006). In praise of convergent thinking. Creativity Research Journal, 18 (3), 391-404.

De Dreu, C. K. W., Baas, M., \& Nijstad, B. A. (2012). The emotive roots of creativity: Basic and applied issues on affect and motivation. In M. D. Mumford (Ed.), Handbook of Organizational Creativity (p.p. 217-240). London: Academic Press.

De Jong, J., \& Den Hartog, D. (2010). Measuring innovative work behaviour. Creativity and Innovation Management, 19 (1), 23-36. doi:10.1111/j.1467-8691.2010.00547.x

Devloo, T., Anseel F., Beuckelaer, A., \& Salanova M. (2015). Keep the fire burning: Reciprocal gains of basic need satisfaction, intrinsic motivation and innovative work behaviour. European Journal of Work and Organizational Psychology, 24 (4), 491-504. doi:10.1080/1359432X.2014.931326 Dorenbosch, L., van Engen, M. L., \& Verhagen, M. (2005). On- the- job innovation: the impact of job design and human resource management through production ownership. Creativity and Innovation Management, 14 (2), 129-141.

Frese, M., Fay, D., Hilburger, T., Leng, K., \& Tag, A. (1997). The concept of personal initiative: Operationalization, reliability and validity in two German samples. Journal of Occupational and Organizational Psychology, 70 (2), 139-161.

Frese, M., Kring, W., Soose, A., \& Zempel, J. (1996). Personal initiative at work: Differences between East and West Germany. Academy of Management Journal, 39 (1), 37-63.

Gagné, M., \& Deci, E. L. (2005). Self-determination theory and work motivation. Journal of Organizational Behavior, 26 (4), $331-362$. doi:10.1002/job.322

Grant, A. M. (2008). Does intrinsic motivation fuel the prosocial fire? Motivational synergy in predicting persistence, performance, and productivity. Journal of Applied Psychology, 93 (1), 48-58. doi:10.1037/0021-9010.93.1.48

Janssen, O., Van de Vliert, E., \& West, M. (2004). The bright and dark sides of individual and group innovation: A special is sue introduction. Journal of Organizational Behavior, 25 (2), 129-145.

Kanter R. M. (1988). When a thousand flowers bloom: Structural, collective, and social conditions for innovation in organizations. Research in Organizational Behavior, 10, 169-211.

Kleysen, R. F., \& Street, C. T. (2001). Toward a multi-dimensional measure of individual innovative behavior. Journal of Intellectual Capital, 2 (3), 284-296.

Messmann, G., \& Mulder, R. H. (2011). Innovative work behaviour in vocational colleges: Understanding how and why innovations are developed. Vocations and Learning, 4 (1), 63-84. doi:10.1007/s12186-010-9049-y

Messmann, G., \& Mulder, R. H. (2012). Development of a measurement instrument for innovative work behaviour as a dynamic and context-bound construct. Human Resource Development International, 15 (1), 43-59. doi:10.1080/13678868.2011.646894

Oreg, S. (2003). Resistance to change: Developing an individual differences measure. Journal of Applied Psychology, 88 (4), $680-693$. doi:10.1037/0021-9010.88.4.680

Pieterse, A. N., van Knippenberg, D., Schippers, M., \& Stam, D. (2009). Transformational and transactional leadership and innovative behavior: The moderating role of psychological empowerment. Journal of Organizational Behavior, 31 (4), 609-623. doi:10.1002/job.650

Ramamoorthy, N., Flood, P., Slattery, T., \& Sardessai, R. (2005). Determinants of innovative work behaviour: Development and test of an integrated model. Creativity and Innovation Management, 14 (2), 142-150.

Ryan, R. M., \& Deci, E. L. (2000). Self-determination theory and the facilitation of intrinsic motivation, social development, and well-being. American Psychologist, 55 (1), 68-78. doi:10.1037110003-066X.55.1.68

Scott, S. G., \& Bruce, R. A. (1994). Determinants of innovative behavior: A path model of individual innovation in the workplace. Academy of Management Journal, 37 (3), 580-607.

Simms, L. J. (2008). Classical and modern methods of psychological scale construction. Social and Personality Psychology Compass, 2 (1), 414433. doi:10.1111/j.1751-9004.2007.00044.x

Spreitzer, G. M. (1995). Psychological empowerment in the workplace: Dimensions, measurement, and validation. Academy of Management Journal, 38 (5), 1442-1465.

Thomas, K. W., \& Velthouse, B. A. (1990). Cognitive elements of empowerment: An "interpretive" model of intrinsic task motivation. Academy of Management Review, 15 (4), 666-681.

Tvarijonavičius, M., \& Bagdžiūnienè, D. (2013). Darbuotojų psichologinis įgalinimas: lietuviškojo tyrimo metodo psichometrinės charakteristikos. Psichologija, 47, 44-60.

Tvarijonavičius, M. (2014). Psichologinis darbuotoju igalinimas: jo prielaidos ir vaidmuo organizacijoje (Daktaro disertacija). Vilniaus universitetas, Vilnius.

Van de Ven, A. H. (1986). Central problems in the management of innovation. Management Science, 32 (5), $590-607$.

West, M. A., \& Farr, J. L. (1989). Innovation at work: Psychological perspectives. Social Behaviour, 4, 15-30.

Young, L. D. (2012). How to promote innovative behavior at work? The role of justice and support within organizations. The Journal of Creative Behavior,46 (3), 220-243. doi: 10.1002/jocb.15 